\title{
Correction to: 14th International Conference on Computational Intelligence in Security for Information Systems and 12th International Conference on European Transnational Educational (CISIS 2021 and ICEUTE 2021)
}

\author{
Juan José Gude Prego, José Gaviria de la Puerta, \\ Pablo García Bringas, Héctor Quintián (D), and Emilio Corchado
}

Correction to:

J. J. Gude Prego et al. (Eds.): 14th International Conference on Computational Intelligence in Security for Information Systems and 12th International Conference on European Transnational Educational (CISIS 2021 and ICEUTE 2021), AISC 1400, https://doi.org/10.1007/978-3-030-87872-6

In the original version of the chapters 9 and 31, the following belated corrections have been incorporated: The author name "Francico Zayas-Gato" has been changed to "Francisco Zayas-Gato". The correction chapters and the book have been updated with the changes.

The updated version of these chapters can be found at 